\title{
経年劣化紙資料の加速劣化試験
}

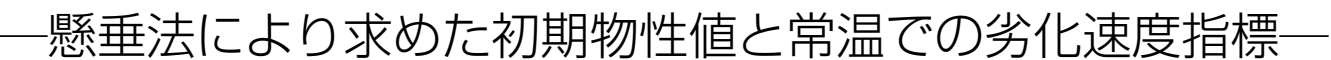

\section{Moist Heat Accelerated Ageing Test of Naturally Aged Pa- per: Prediction Initial Physical Properties and Degradation Rate Indicator at Room Temperature by Suspension Method}

\author{
東京藝術大学大学院 ${ }^{* 1}$ 美術研究科 \\ 李 壃 $* 2$, 稲葉政満
}

Kang Lee ${ }^{* 2}$ and Masamitsu Inaba

Graduate School of Fine Arts, Tokyo University of the Arts*1

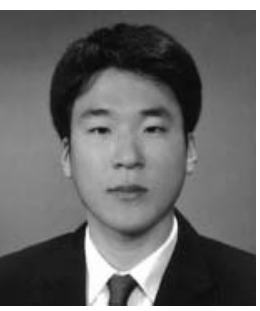

李壃

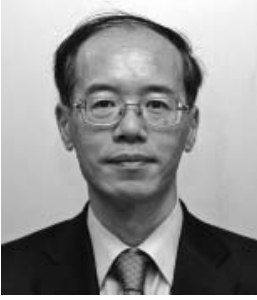

稲葉政満

\begin{abstract}
In order to take measures for preventing degradation of paper whose permanence is low, like acid paper, and saving them in a better state for a long time, it is preferable to estimate the natural ageing rate of various types of papers and to predict their life expectancy. Conventionally, the permanence of paper is evaluated by artificially ageing paper at a single temperature, but it has been reported that if paper deteriorates differently at different temperatures, the assumed permanence of paper at a single high temperature will differ from that at room temperature.

Thus, in this research, 11 naturally aged books from the Journal of the Chemical Society published in Britain that had deteriorated over time for 130 to 80 years were selected and further aged artificially under 4 temperature conditions between 60 and $90^{\circ} \mathrm{C}$ ( $65 \%$ r. h. constant). It was possible to obtain the degradation rates of tear index, burst index, degree of polymerization and discolouration at room temperature by Arrhenius plots with high correlation coefficient (more than 0.97 ). Initial physical properties were calculated by estimated degradation rates, current physical properties and time that elapsed from the publication of the sample books. The degradation rate indicator (degradation rate constant divided by tear or burst index) were calculated as in our previous research, since the higher the physical properties, the lower the degradation rate of tear or burst index was. Better correlation was observed between the concentration of hydrogen ion before moist heat accelerated ageing and the degradation rate indicator of the physical properties of paper at room temperature than at higher temperature.
\end{abstract}

Keywords : acidic paper, degradation rate, natural ageing, accelerated ageing, arrhenius plot, activation energy 分類 : $\mathrm{S}_{1}$ 紙の性質, $\mathrm{Y}_{0}$ その他

\footnotetext{
${ }^{* 1}$ T110-8714 東京都台東区上野公園 12-8/12-8 Uenokoen, Taito-ku, Tokyo 110-8714, Japan

${ }^{* 2} \mathrm{E}-$ mail : nigitaz@hotmail.com 


\section{1. 緒言}

酸性紙の劣化問題が生じたのは，19 世紀前半期に発明 され広まったロジンサイズを用いた酸性抄紙が導入された ことによる ${ }^{1)}$ 。酸性紙のような保存性の低い紙資料を，よ り良い状態で長期間保存し, 劣化を阻止するための対策を 立てるためには，個々の酸性紙の経年劣化速度を推定する ことにより，期待寿命を予測することが望ましい。そのた めの最も正確な方法は常温の保存環境に実際に試験紙を置 いてその劣化速度を求めることであるが，その結果が出る までには長期間を要する。そのため, 紙を湿熱や光などの 極端な条件下で強制的に劣化させることにより紙の保存性 を評価している ${ }^{2)}$ 。

従来の紙の保存性評価において，単一の温度条件による 加速劣化は, 紙試料間で劣化機構が異なる場合, 高温と常 温で評価した保存性が異なり得ることが報告されている3)。

130 年から 80 年程度経年劣化した紙を入手したので，こ の試料を用いて経年劣化と加速劣化の比較を行うことを計 画した。前報)では，その手始めとして $80^{\circ} \mathrm{C} ， 65 \%$ r. h. の 単一条件での湿熱劣化試験を行い，経年劣化した紙資料中 に有機酸が多いほど，その後の湿熱劣化により紙の物性が 低下しやすく, この時, セルロースの切断もより多く生じ ていることを明らかにした。しかし，セルロースの切断数 は酸加水分解反応の指標である水素イオン濃度のみには単 純に相関せず，酸化反応も試料によりその寄与は異なるが， 同時に生じていることを明らかにした。

本研究では，湿度 $65 \%$ r. h. 一定であるが，前報の $80^{\circ} \mathrm{C}$ に数段階の温度条件での湿熱劣化処理を追加し，紙の諸物 性の常温での劣化速度を推定し, 紙の酸加水分解反応の因 子である水素イオン濃度と比較した結果を報告する。

\section{2. 実験}

\section{1 紙 試 料}

実験に用いた経年劣化した紙資料は，イギリスで刊行さ れた Journal of the Chemical Society の 1878 年から 1923 年 発行分であり，入手した時点で，全てハードカバーで合冊 製本されている。この中から紙の劣化状態を考慮して前報 で選択した代表的な資料 11 冊を選び，実験に供した。

選んだ冊子中から，図書資料の前後 200 ページを避けた 各巻の中心部の紙で，前報と同様にできる限り類似した紙 を選択して用いた。また，1枚の紙中では四方の端から 2 $\mathrm{cm}$ 離れた中心部分を対象とした。なお，インクの有無は 無視することとした。

Graff C 溶液を用いて繊維同定試験（JIS-P 8120：1998） を行い，顕微鏡観察により繊維配合比を調査し，1878 年 〜1897 年資料の繊維組成は，エスパルトを中心とした綿 ぼろ, 麻類混合パルプであることから ECL, 1902 年〜1913 年資料では，エスパルト，針葉樹混合パルプで ES，1918 年〜1923 年資料では，針葉樹パルプで S と略した（Table 1）。なお，年代別試料の繊維配合比率を前報 ${ }^{4} て ゙$ 報告して いるが，参考のために Fig. 1 に再掲する。

\section{2 強制劣化試験}

JIS P 8154-3：2008 に従い，紙試料を恒温恒湿槽（プラ チナス $\mathrm{PH}-3 \mathrm{KT}, \mathrm{Espec}$ 社製）内に吊るして湿度 $65 \%$ r. h. 一定で，数段階の温度 $\left(90^{\circ} \mathrm{C}, 80^{\circ} \mathrm{C}, 70^{\circ} \mathrm{C}, 60^{\circ} \mathrm{C}\right)$ 条件下 で湿熱劣化させた。この方法での湿熱劣化を筆者らは挿入 法 ${ }^{5)}$ やチューブ法 ${ }^{2)}$ と区別するため懸垂法 ${ }^{5)}$ と呼んでいる。

\section{3 物理強度測定}

物理強度試験は JIS 法に準拠して $23^{\circ} \mathrm{C} ， 50 \%$ r. h. の恒 温恒湿室中で行った。引裂強さは，デジタルエレメンドル フ引裂試験機（東洋精機製，Elemendorf SA 型）を用い て所定のサイズの試料 4 枚を 1 度に縦方向（繊維配向の高 い方向，今回の試料では頁によって紙の取り方が異なって いた）に引裂いた（JIS P 8116：2000）。破裂強さは，ミュー レン破裂試験機(東洋精機製，Mullen Burst Tester M 2 LD 型）を用いて測定した（JIS P 8112：1994）。

\section{4 色 測 定}

色差計 (浅枝製作所， $45^{\circ} / 0^{\circ}$ ) を用い，下にろ紙 (Adventec，No.2）を 12 枚敷いて，試料画像を取り込み，この 画像中から印字されていない部分を選択して $L^{*} a^{*} b^{*}$ 值 (D 65，10 視野）を求めた。

\section{5 重合度測定}

$0.2 \mathrm{~mol} / \mathrm{L}$ のボラン-tert-ブチルアミン錯体水溶液で 還元処理した試料を $0.5 \mathrm{~mol} / \mathrm{L}$ の銅エチレンジアミン $(\mathrm{CuED})$ 溶液に溶解 $(2.5 \mathrm{mg} / \mathrm{mL}) し て 25.0 \pm 0.1^{\circ} \mathrm{C}$ 条 件でキャノンフェンスケ粘度計（50 番）を用いて粘度を 求めた。前報で述べたように，Martinの式により一点の

Table 1 Fibre type and publication year of paper samples

\begin{tabular}{ll}
\hline Fibre Type & Publication year \\
\hline ECL & $1878,1880,1892,1897$ \\
\hline ES & $1902,1908,1909,1913$ \\
\hline S & $1918,1920,1923$ \\
\hline
\end{tabular}

E: Esparto, C:Cotton, L : Linen,

S : Softwood

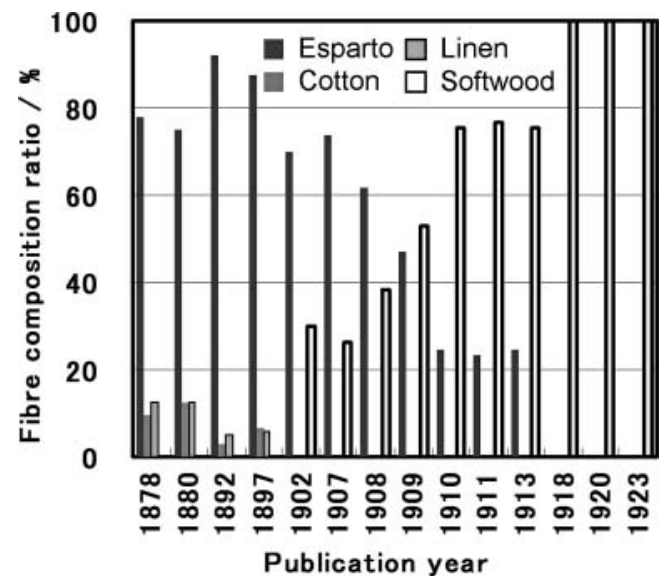

Fig. 1 Fibre composition ratio of papers used in the experiment 
濃度の測定から固有粘度を算出し, Mark-Houwink-桜田 の式により粘度平均重合度 $\left(D P_{v}\right)$ を求めた ${ }^{6)}$ 。

\section{$2.6 \mathrm{p} \mathrm{H}$ 測 定}

紙試料 $0.1 \mathrm{~g}$ を超純水 $1 \mathrm{~mL}$ に浸漬し， $50^{\circ} \mathrm{C}$ で 30 分間， 超音波処理して得られた抽出液 $200 \mu \mathrm{L}$ を $\mathrm{pH}$ メー夕 （Twin pH B 212，堀場製作所）の測定部に滴下して pH を 測定した。

\section{3. 結果と考察}

\section{1 アレニウス・プロットの作成}

前報で求めた $80^{\circ} \mathrm{C}$ の劣化温度での結果に $90^{\circ} \mathrm{C}, 70^{\circ} \mathrm{C}$, $60^{\circ} \mathrm{C}$ の結果を加えて，アレニウス・プロットにより常温 $\left(23^{\circ} \mathrm{C}\right)$ での劣化速度を求めた。 $90^{\circ} \mathrm{C}, 80^{\circ} \mathrm{C}, 70^{\circ} \mathrm{C}, 60^{\circ} \mathrm{C}$ と処理温度条件を変えて経時的に測定した比引裂強さの測 定值を Fig. 2 に示す。劣化時間が長くなるにつれて比引 裂強さは低下して行き, 劣化温度が高くなるほど, その低 下の度合いも大きくなる。前報と同様に各温度での劣化速 度定数 $k$ を $S c=S_{0} \exp (-k t)\left(S_{0}\right.$ は初期值 $)$ より求めた。得 られたデータは最初この近似式にフィットするが，その後， 劣化が進むにつれて変化がなだらかになり, 近似式から外 れる傾向を示したので, 全体の測定值の中で劣化初期のよ く近似できる期間までのデー夕を使って劣化速度定数を求 めた。Fig. 2 では縦軸を対数にしているので, 各直線を引 いた範囲がその例である。比破裂強さや重合度に関しても 同様の方法で $k$ を求めた。

一方，Fig. 3 に示す明度差（ $\left.\Delta L^{*}\right)^{\text {i玉1 }}$ の増大に関しては, 本紙試料の変色に最も寄与しており, 時間の平方根と $\Delta L^{*}$ をプロットすると直線近似できたので, その直線の傾きを 変色速度とし, $\Delta L^{*}=-k \sqrt{t}$ より変色速度定数 $k$ を求めた。

アレニウスの式(1)では, 均一系での素反応で, 横軸の絶 対温度 $\mathrm{T}$ の逆数と縦軸の劣化する速度定数 $k$ などとの関 係がグラフ上で直線になることが知られている。紙のよう な複雑な系（複合反応）では, その劣化に様々な素反応が 関与しているため, そのプロットは必ずしも直線上の変化 を示すとは限らない。Fig. 4 が紙の比引裂強さに対する劣 化速度定数を用いたアレニウス・プロットの一例である。 結果を見ると，11種の全ての試料が $60^{\circ} \mathrm{C}$ から $90^{\circ} \mathrm{C}$ の温 度範囲内で 0.97 以上の高い相関係数でアレニウスの式に

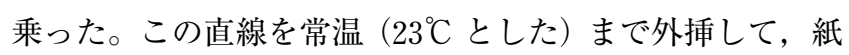
の常温での経年劣化速度を推定した。比破裂強さ, 重合度 及び明度差の速度定数の場合においても 0.97 以上の高い 相関係数でアレニウスの式が成立した。

$$
k=A \mathrm{e}^{-\frac{E_{a}}{R T}}
$$

注1) 変色の度合い(色差)を

$\Delta E^{*} a b=\sqrt{\left(\Delta L^{*}\right)^{2}+\left(\Delta a^{*}\right)^{2}+\left(\Delta b^{*}\right)^{2}}$

で表す。 $\Delta E^{*} a b$ の劣化前の初期值は理論上, $\Delta L^{*}, \Delta a^{*}$, $\Delta b^{*}$ それぞれの常温での劣化速度定数から初期值を求めて 上記の式により算出できるが, $\Delta a^{*}$ の変化挙動がばらつい ており，速度論的考察ができなかったため， $\Delta L^{*}$ を以後の 検討で用いることとした。

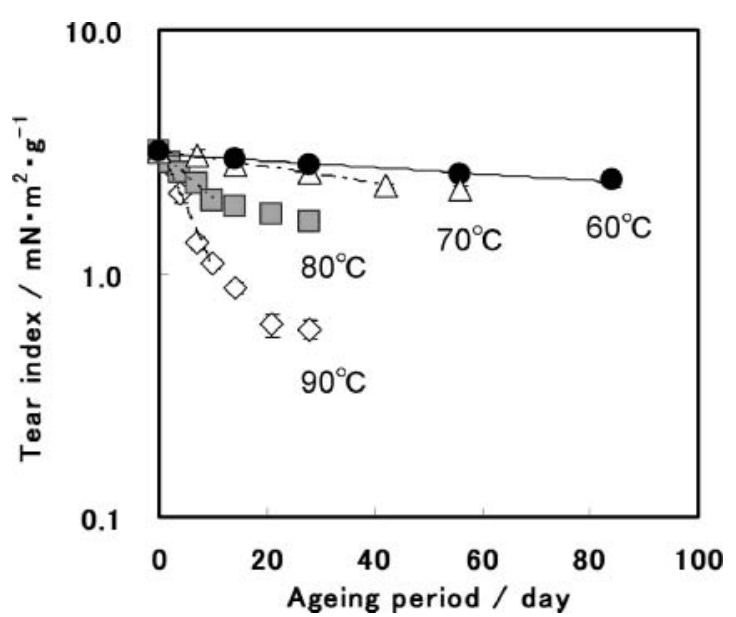

Fig. 2 Change in tear index by moist heat accelerated ageing test at various temperature

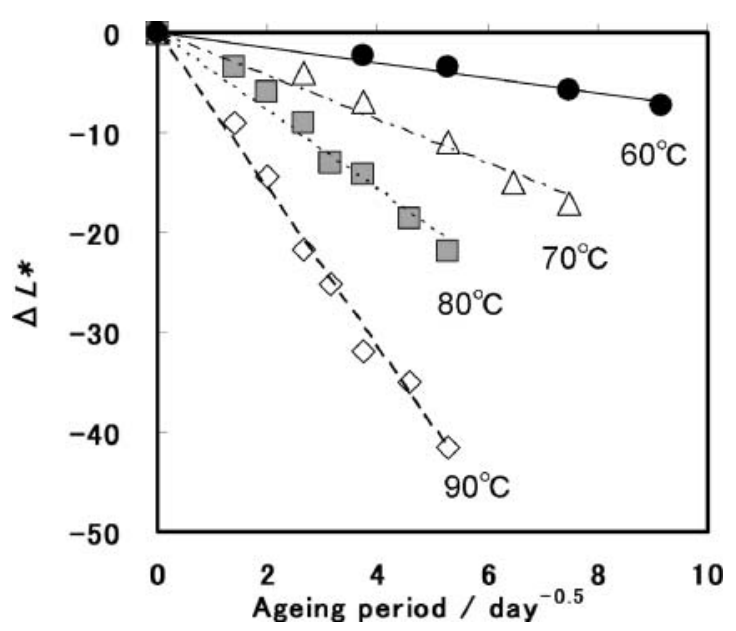

Fig. 3 Change in $\Delta L^{*}$ by moist heat accelerated ageing test at various temperature

( $k=$ rate constant, $A=$ frequency factor, $R=$ universal gas constant, $T=$ temperature, $E_{a}=$ activation energy)

アレニウス・プロットより反応の活性化エネルギーを求 めた結果を Table 2 に示す。セルロースの解重合反応の活 性化エネルギーはこれまで, Begin ら $(2002)^{7)}$ が 100\% 針 葉樹晒クラフトパルプとケミサーモメカニカルパルプで 103 118 kJ/mol を報告しており，Zouら $(1996)^{8)}$ が針葉 樹晒バイサルファイトパルプと針葉樹晒クラフトパルプで 104 113 kJ/mol を報告するなど，パルプの種類や蒸解方 法が異なる紙に関して類似する活性化エネルギーを算出し ている。本試料では， $68 \sim 134 \mathrm{~kJ} / \mathrm{mol}$ であり，これらの 結果と類似したのは 11 点中 3 点であり, その前後に大き くずれているものが多かった。湿熱劣化前の物理強度と重 合度が低く，有機酸量が多いような経年劣化が進行してい る ECL 試料の一部と ES 試料は文献值を下回っており, 1918，1923 年の S 試料では高めの值を示した。ただし，後 に述べるように 1913 年から以後の針葉樹パルプ主体の紙 の重合度変化はあまり変化しておらず，これらの值には問 題があるかもしれない。

本報告で求めた比引裂強さの劣化速度では, 活性化エネ 

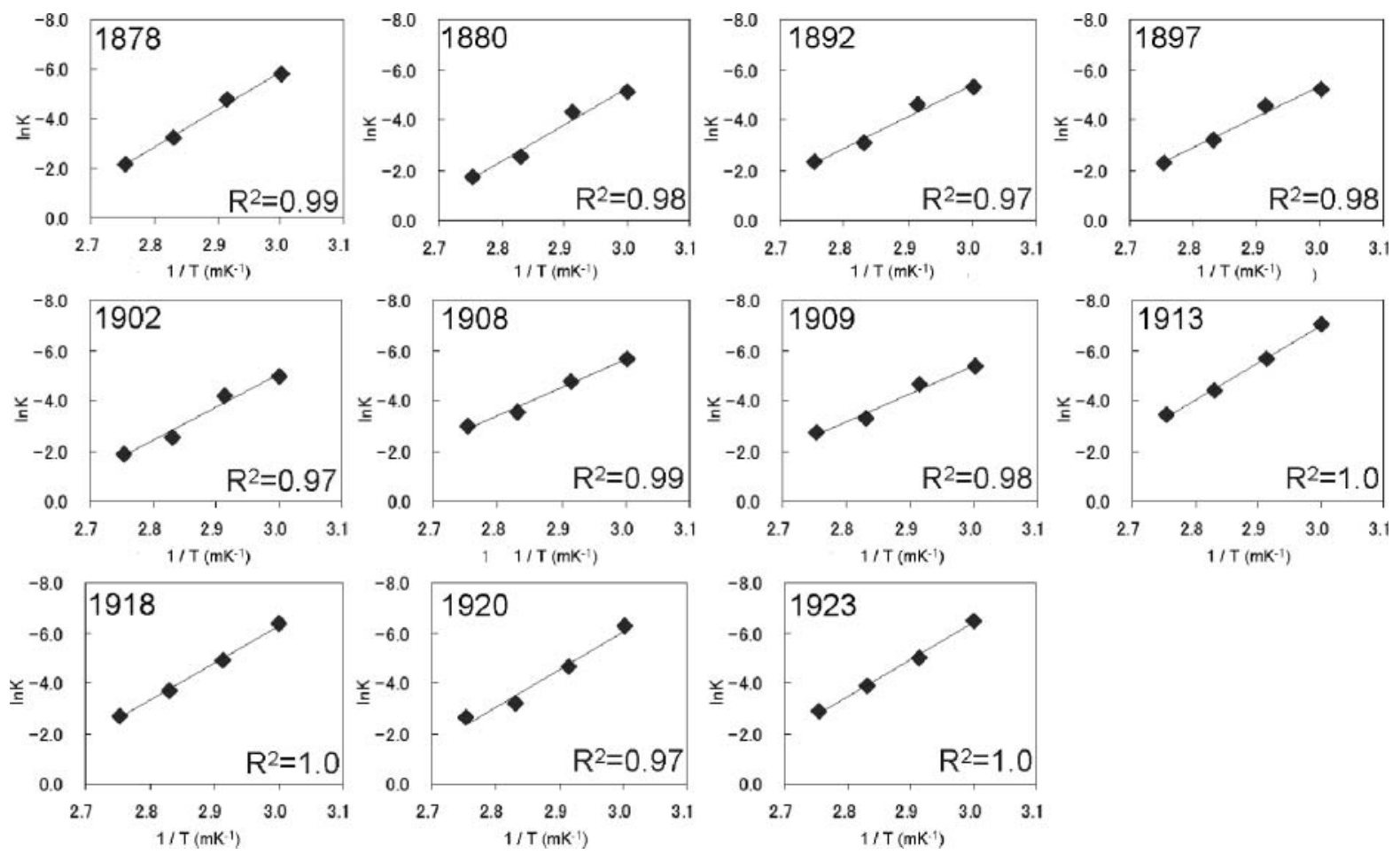

Fig. 4 Arrhenius plots against to degradation rate constant $(k)$ of tear index

ルギーは 93〜 $125 \mathrm{~kJ} / \mathrm{mol}$ であり，解重合の場合と同じく， 試料全体で值がばらついた。Begin ら (2002) ${ }^{7}$ は $100 \%$ 針 葉樹晒クラフトパルプとケミサーモメカニカルパルプで 102〜 $144 \mathrm{~kJ} / \mathrm{mol}$ を報告しており，この場合も 1908 年, 1909 年の $\mathrm{ES}$ 試料は文献值を下回った。

本報告で求めた比破裂強さの劣化速度では, 活性化エネ ルギーは 115〜 $131 \mathrm{~kJ} / \mathrm{mol}$ で, 解重合や比引裂強さの場合 に比べて全ての紙試料で近い值を示した。明度差の変化速 度では, 活性化エネルギーは $97 \sim 125 \mathrm{~kJ} / \mathrm{mol}$ であった。比 破裂強さ及び明度の低下反応の活性化エネルギーに関して は，既往の研究での報告が見当たらなかった。

\section{2 紙の諸物性の常温での劣化速度指標と初期物性値} の推定

前報の $80^{\circ} \mathrm{C}, 65 \%$ r. h. での結果で用いた紙の諸物性の 劣化速度指標注 (劣化速度定数/初期物性值) を算出して 検討する。そのために, 紙の諸物性のそれぞれの初期值を 推定した。初期值の算出については，3.1のアレニウス・ プロットから求めた常温での劣化速度定数 $k$ と $S c$ で表す 湿熱劣化前の現状での物性值, そして, $t$ で表す刊行から の経過時間を使って, 劣化速度定数を求めた式により刊行 時の初期物性值 $S_{0}$ を推定した。明度に関しては, 加速劣 化による明度の変化挙動 $L^{*}{ }_{0}=L^{* c}+k \sqrt{t}$ によって初期值

注2) 前報で述べたように劣化速度は初期值が高いものほど大 きい傾向が認められるため, 筆者らは劣化速度定数を初期 物性值で除した值を劣化速度指標として定義して用いる。 なお, 劣化速度指標を学会発表などで劣化速度指標と呼ん だが，この名称は英語で混乱が生じるため, 以後劣化速度 指標と呼ぶこととする。
Table 2 Activation energy $\left(E_{a}\right)$ of deterioration reaction of several properties

\begin{tabular}{ccccc}
\hline Year & Depolymerization & Tear index & Burst index & $\Delta L^{*}$ \\
\hline 1878 & 104 & 124 & 115 & 111 \\
\hline 1880 & 80 & 121 & 122 & 103 \\
\hline 1892 & 74 & 106 & 122 & 119 \\
\hline 1897 & 73 & 103 & 118 & 124 \\
\hline 1902 & 82 & 109 & 119 & 97 \\
\hline 1908 & 71 & 93 & 131 & 99 \\
\hline 1909 & 68 & 94 & 125 & 106 \\
\hline 1913 & 118 & 121 & 120 & 125 \\
\hline 1918 & 159 & 123 & 114 & 113 \\
\hline 1920 & 119 & 125 & 122 & 100 \\
\hline 1923 & 134 & 121 & 106 & 107 \\
\hline & & & $\left(E_{a} / \mathrm{kj}^{*} \mathrm{~mol}^{-1}\right)$
\end{tabular}

$L^{*}{ }_{0}$ を推定した。

湿熱劣化前の現状での物性值に対して推定した初期物性 值が相互に比例する関係なのか，全試料において類似する 初期物性の紙が使用されていたかを見るために，湿熱劣化 前の紙の物性值と推定した初期值を比較した。重合度と $\Delta L^{*}$ の劣化速度定数は $80^{\circ} \mathrm{C}$ など高温ではある程度の大き さを示したが，常温では極めて小さくなり，湿熱劣化前の 值と初期值がほぼ同じであった。比破裂強さ（Fig.5(B)） 


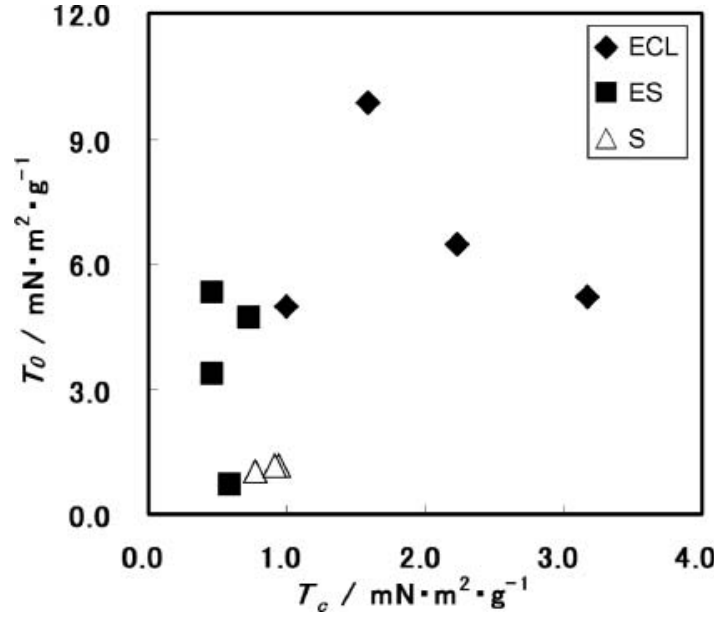

Fig. 5(A) Relationship between the current tear index value $\left(T_{c}\right)$ and predicted initial tear index $\left(T_{0}\right)$

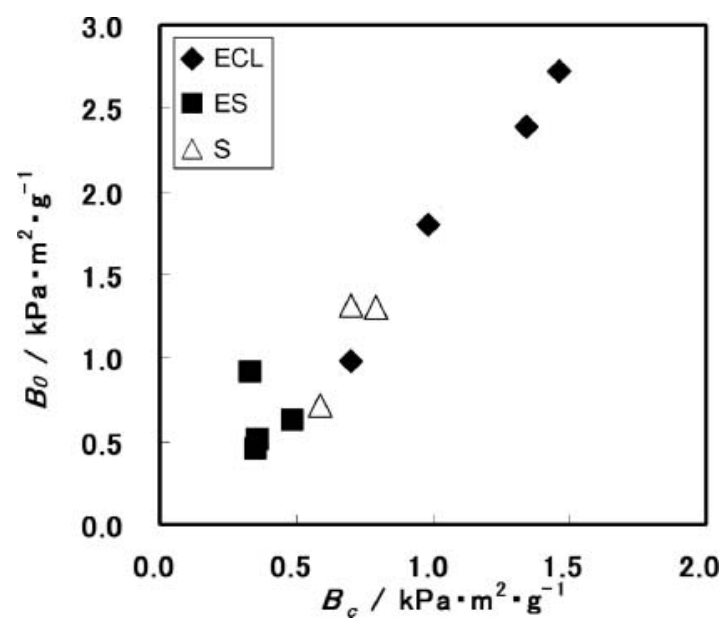

Fig. 5(B) Relationship between the current Burst index value $\left(\boldsymbol{B}_{c}\right)$ and predicted initial tear index $\left(\boldsymbol{B}_{0}\right)$

に関しては湿熱劣化前の值が高い紙試料ほど，初期值も高 くなる傾向を示した。一方，比引裂強さ（Fig.5(A)）で は少しばらつく傾向を示した。

次に, 推定した常温での劣化速度定数を初期物性值で除 して劣化速度指標を算出した。推定した重合度，比引裂強 さの常温での劣化速度指標の結果を Fig. 6〜9に示す。 ECL，ES 試料の 1878 年から 1909 年にかけて重合度及び 比引裂強さの劣化速度指標は同様に大きくなった。これは, 比引裂強さの低下は単繊維強さの寄与が大きく, また, 重 合度の低下が単繊維強さの低下に寄与するためと考えられ る。しかし, 詳細に検討すると, 比引裂強さの常温での劣 化速度指標における ECLの 1897 年と ES の 1909 年試料 が小さくなっているように見える。その原因は現在のとこ ろ不明であるが，これが Fig. 5(A) の湿熱劣化前と推定し た初期の比引裂強さを比較した結果がばらついた原因と なっている。また，針葉樹パルプを 8 割以上配合している $\mathrm{ES}$ 試料の 1913 年と針葉樹試料（1918～1923）は比引裂強 さが類似する傾向を示した。さらに，これらの試料の重合 度（Fig. 6) はほとんど低下しないにも関わらず，物理強

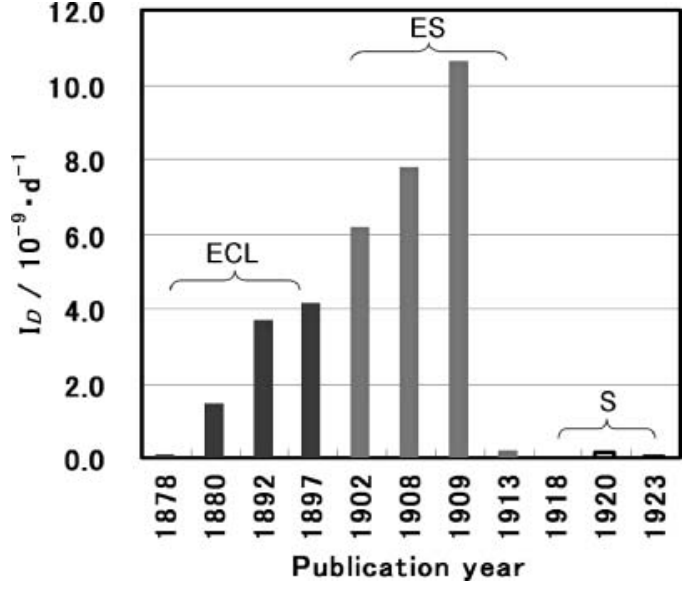

Fig. 6 Predicted degradation rate indicator of $D P_{v}\left(I_{D}\right)$ at room temperature $\left(23^{\circ} \mathrm{C}\right)$

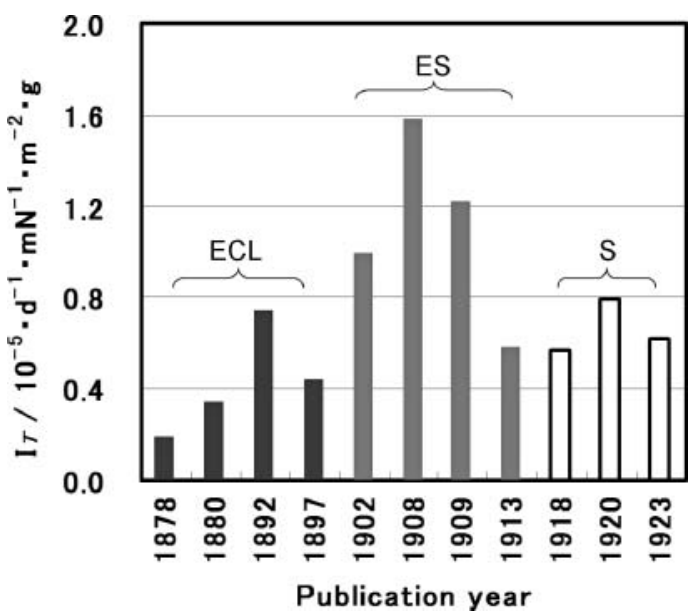

Fig. 7 Predicted degradation rate indicator of tear $\left(I_{T}\right)$ at room temperature $\left(23^{\circ} \mathrm{C}\right)$

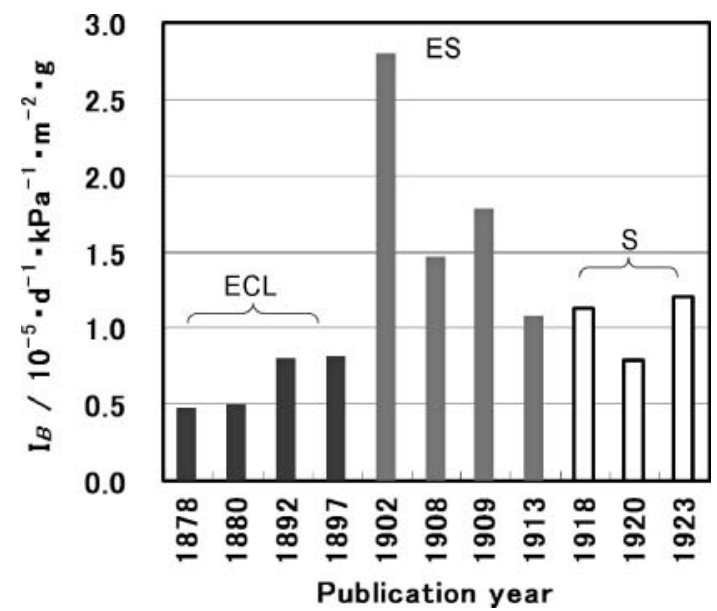

Fig. 8 Predicted degradation rate indicator of burst $\left(I_{B}\right)$ at room temperature $\left(23^{\circ} \mathrm{C}\right)$

度（Fig.7，8）では低下が速いような別の傾向を示した。 同様に比破裂強さの常温での劣化速度指標における 1902 年試料 1 点が突出（Fig. 8）しており，これも Fig. 5(B)で 異常值が生じた原因となっている。 


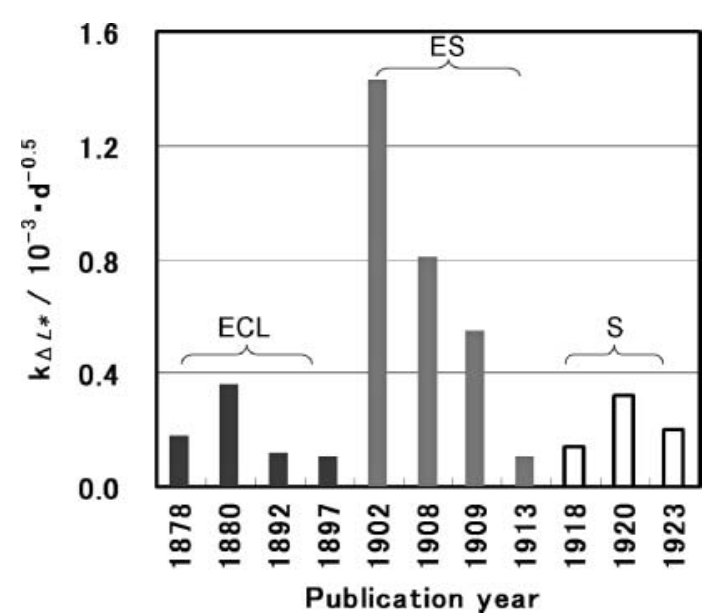

Fig. 9 Predicted discolouration rate of $\Delta L^{*}$ at room temperature $\left(23^{\circ} \mathrm{C}\right)$

比破裂強さと明度差（Fig. 9）の常温での劣化速度指標 についても ES 試料が他の試料に比べて劣化が最も進行し ている傾向を示した。

異なる繊維組成や現状での物性を持つ紙試料の経年劣化 がどれほど進行しているかを見るために, 湿熱劣化前の重 合度, 比引裂強さと常温での劣化速度指標を比較した結果 を Fig. 10 に示す。湿熱劣化前の物性值が高い紙試料ほど, 常温での劣化速度指標が低くなった。つまり, 現状での物 性が高い紙試料ほど, 製造時の物性が高く, 常温環境では 劣化しにくい紙であることが分かった。これらの結果は, 製造年代の異なる本紙試料の初期の物理的, 化学的性質が 近似し, 現状での物性值に対して推定した初期值同士が類 似するであろうという筆者らの期待とは異なる結果であっ たことになるが, 劣化が進行すると劣化速度が低下する傾 向が認められることを考慮すると, より劣化している試料 の劣化速度定数を過小に評価していることも考えられる。

重合度では, 1913 年の $\mathrm{ES}$ 試料と $\mathrm{S}$ 試料の湿熱劣化前 の低い重合度にも関わらず，加速劣化による低下が遅いよ うな別の挙動を示した。

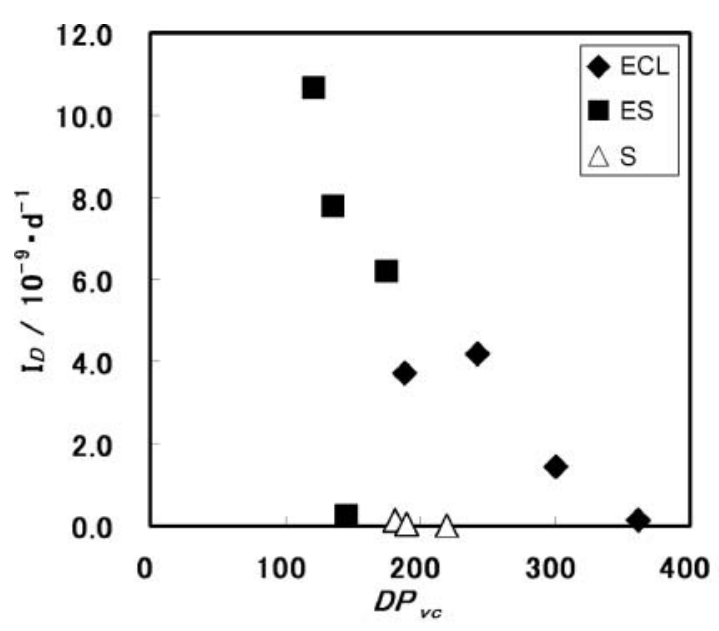

(A) Viscosity average degree of polymerization $\left(D P_{v}\right)$
3.3 常温での劣化速度指標と水素イオン濃度との比較 紙の主成分であるセルロース鎖を分解するのに，酸加水 分解反応が大きく寄与している場合にはセルロースの解重 合と水素イオン濃度が相関する。今回推定した常温での劣 化速度指標が紙試料の保存性を評価する上で妥当であるか を見るために，Fig. 11 に湿熱劣化前の紙の水素イオン濃 度と今回推定した紙の重合度の常温 $\left(23^{\circ} \mathrm{C}\right)$ での劣化速度 指標とをプロットし，これを同じく $80^{\circ} \mathrm{C} て ゙$ 加速劣化した ときの結果（前報 ${ }^{4)} の$ 図を再掲）とを比較した。その結果, 水素イオン濃度が高い紙試料ほど劣化が速く進むという関 係が， $80^{\circ} \mathrm{C}$ より常温での $23^{\circ} \mathrm{C}$ の方で良い相関を示した。 すなわち, 高温の単一条件での加速劣化より良い相関が得 られた。

このように紙の諸物性の $23^{\circ} \mathrm{C}$ と $80^{\circ} \mathrm{C}$ での劣化速度指標 と水素イオン濃度を比較した結果が異なる理由について, $\mathrm{ES}$ 試料の 2 点の重合度のアレニウス・プロットを Fig. 12 に示す。ここで回帰直線の傾きが異なることは, 紙試料に より劣化に寄与している素反応の寄与程度が試料によって 異なっているために, 温度変化したときの素反応の全反応 に対する寄与程度が試料によって異なるためと考えている。 今後さらにセルロースの酸化度の違いなどの面から検討す る予定である。

\section{4. ま と め}

経年劣化した紙資料を前報の $80^{\circ} \mathrm{C}$ に加え， $90^{\circ} \mathrm{C}, 70^{\circ} \mathrm{C}$, $60^{\circ} \mathrm{C}$ を合わせて 4 段階の温度条件（湿度 $65 \%$ r. h. 一定） で湿熱劣化させ, 重合度, 比引裂強さ, 比破裂強さ, 明度 の劣化速度定数に関して高い相関係数で成立するアレニウ ス・プロットを作成し, 反応の活性化エネルギー, 常温で の劣化速度や初期物性值を推定した。前報と同様に, 紙物 性の常温での劣化速度定数を推定した初期物性值で除して 常温での劣化速度指標を算出したところ, 現在の物性值が 高い紙試料ほど, 常温での劣化速度指標は低く, つまり, 常温環境において劣化しにくい紙であることを示した。そ して, 紙物性の常温での劣化速度指標を湿熱劣化前の水素

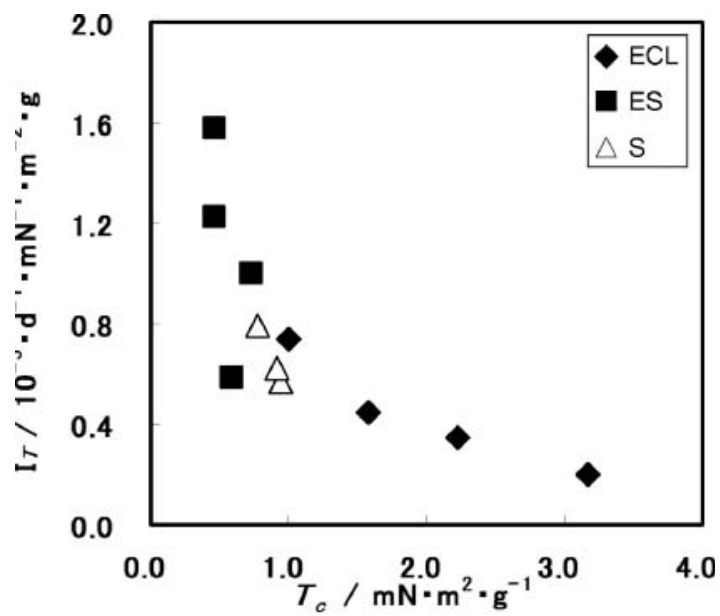

(B) Tear index

Fig. 10 Relationship between the current value $(c)$ and predicted degradation rate indicator (I) 


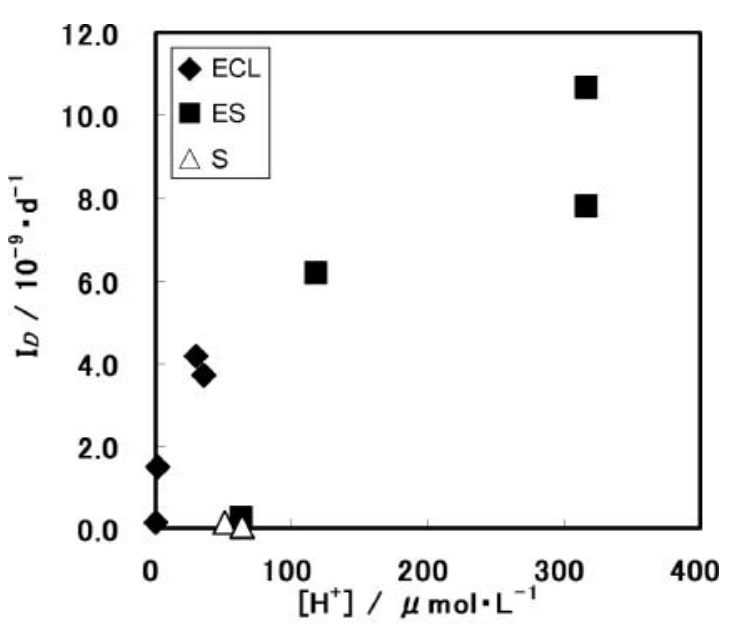

$\left(23^{\circ} \mathrm{C}\right)$

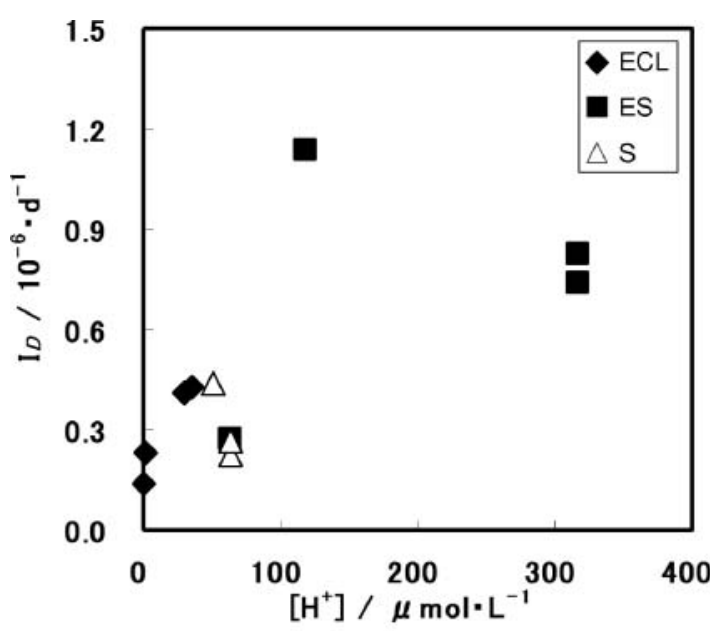

$\left(80^{\circ} \mathrm{C}\right)$

Fig. 11 Relationship between the current concentration of hyfrogen ion and predicted degradation rate indicator of $D P_{v}$ at room temperature $\left(23^{\circ} \mathrm{C}\right)$ and $\left(80^{\circ} \mathrm{C}\right)$

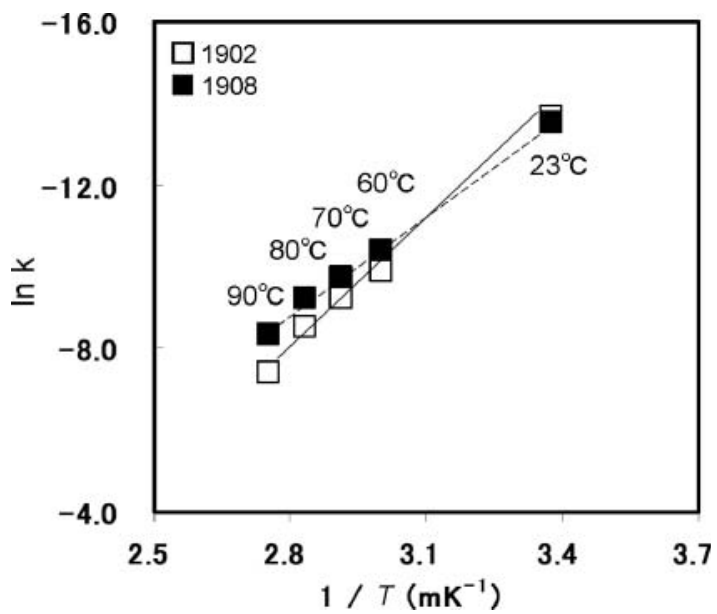

Fig. 12 Arrhenius plots against to degradation rate constant of $D P_{v}$ (ES samples)
イオン濃度と比較することにより，高温の単一条件での加 速劣化より良い相関が得られた。

\section{References}

1) Barrow, W. J., Reavis, C. : Science 1291075 (1959)

2) Shahani, C. J., Lee, S. B., Hengemihle, F. H., Harrison, G., Song, P., Sierra, M. L., Ryan, C. C., Weberg, N. : Accelerated Aging of Paper, Library of Congress, 2001, 11

3）大江礼三郎，吉田拓：保存図書の酸性化対策に関する 研究, 紙の劣化速度に関する試験, 昭和 $60 \cdot 61$ 年度 科学研究費助成金総合研究 (A) 研究報告書, 1987,95

4) Lee, K., Inaba, M. : Restaurator 3481 (2013)

5）坪倉早智子, 近藤文, 豊竹幸恵, 山口佳奈, 稲葉政満 : 文化財保存修復学会誌 55 25（2010）

6) Santucci, L., Zappala, M. P. : Restaurator 2251 (2001)

7) Begin, P. L., Kaminska, E. : Restaurator 2389 (2002)

8) Zou, X., Uesaka, T., Gurnagul, N. : Cellulose 3 (1) 243 (1996)

(受理：2013.6.3) 